\title{
Influence of Weathering and Correlations Between Wave Propagation Velocity and Durability with Physical and Mechanical Parameters in Phyllites
}

\author{
T.R.R. Carvalho, M.F. Leão, E.A.G. Marques
}

\begin{abstract}
Ultrasonic longitudinal wave velocity $(V p)$ and durability are characteristics largely determined in geotechnical evaluations. These properties are useful in the analysis of weathered rocks because they usually have good relationships with physical and mechanical properties of rocks. Additionally, the tests to obtain these parameters are easy to perform. However, few studies have been performed specifically on low degree metamorphic rocks. The purpose of this study is to evaluate the influence of weathering on these parameters, as to propose correlations between $V p$ and some mechanical and physical parameters. This study was carried out using phyllites from three weathering profiles located along the highway BR-356, Minas Gerais, Brazil. The results reveal a clear influence of weathering on $V p$ and durability mainly due to increased porosity. However, as the variation of this parameter is heterogeneous, the relationship between $V p$, durability, and weathering is not uniform, although they present general trends. The behavior shown by porosity reflects the complex role of chemical weathering on fractures. The non-uniform pattern of $V p$ and durability throughout the weathering classes is also a consequence of the heterogeneity and anisotropy intrinsic to these phyllites. The empirical relationships established exhibit good correlation coefficients.
\end{abstract}

Keywords: correlations, durability, Minas Gerais, phyllite, wave propagation velocity, weathering.

\section{Introduction}

Ultrasonic wave propagation test is non-destructive, easy to apply, and thus has been increasingly employed in the characterization of rocks for engineering purposes, including the determination of effects of weathering on rocky materials.

Several researchers have studied the relationship between ultrasonic longitudinal wave propagation velocity $(\mathrm{Vp})$ and rock properties, finding an intimate relationship between them (Gardner et al., 1974; Gaviglio, 1989; Souza et al., 2005; Çobanoglu \&Çelik, 2008; Sharma et al., 2011; Nefeslioglu, 2013; Jamshidi et al., 2016; Wen et al., 2018, Kanji \& Leão, 2020). Although many attempts have been performed to correlate $V p$ with physical and mechanical rock properties, few studies have focused on low and medium degree metamorphic rocks (Sharma \& Singh, 2008; Sarkar et al., 2012; Khandelwal, 2013).

Ultrasonic longitudinal wave propagation velocity $(V p)$ in rocks is influenced by many factors such as lithology, density, porosity, grain size and shape, anisotropy, confinement pressure, weathering, bedding, joint characteristics (fill material, water, direction, dip, among others) (Kahraman, 2001).
Weathering is known to lead to rapid changes in the properties of rock materials. Alterations of a particular rock type and their rate of occurrence (alterability) are often described by a durability parameter (Crosta, 1998) known as the durability index $\left(I_{d}\right)$ and obtained through slake durability test.

The slake durability test is used to evaluate the resistance to rock alteration as a function of the disintegration resulting from a standard wetting and drying cycle (Franklin \& Chandra, 1972). Durability is a characteristic largely affected by mineralogy, texture, porosity, and water content and is strongly related to the history of alteration after its formation (Koncagül \& Santi, 1999; Cetin et al., 2000; Dhakal et al., 2002; Yilmaz \& Karacan, 2005; Gupta \& Ahmed, 2007; Ioanna et al., 2009).

In this sense, this study shows the effects of weathering on $V p$ and durability, as well as the correlation between these properties and physical and mechanical parameters in phyllites from the region of Minas Gerais, Brazil.

Phyllites were collected in road slopes located in the state of Minas Gerais, Brazil. These slopes are inserted in the geological context of the Iron Quadrangle, an important mineral province of Brazil, consisting of five main lithostratigraphic units (Alkmim \& Marshak, 1998): crystalline

Tatiane Robaina Rangel de Carvalho, Ph.D. Student, Departamento de Engenharia Civil, Universidade Federal de Viçosa, Viçosa, MG, Brazil. e-mail: tatianerrcarvalho@gmail.com.

Marcio Fernandes Leão, D.Sc., Senior Research, Departamento de Engenharia Civil, Universidade Federal de Viçosa, Viçosa, MG, Brazil. e-mail: marciotriton@ hotmail.com. Eduardo Antonio Gomes Marques, D.Sc., Full Professor, Departamento de Engenharia Civil, Universidade Federal de Viçosa, Viçosa, MG, Brazil. e-mail: eagmarques1965@gmail.com.

Submitted on March 31, 2020; Final Acceptance on April 22, 2020; Discussion open until September 30, 2020.

DOI: $10.28927 /$ SR.432297 


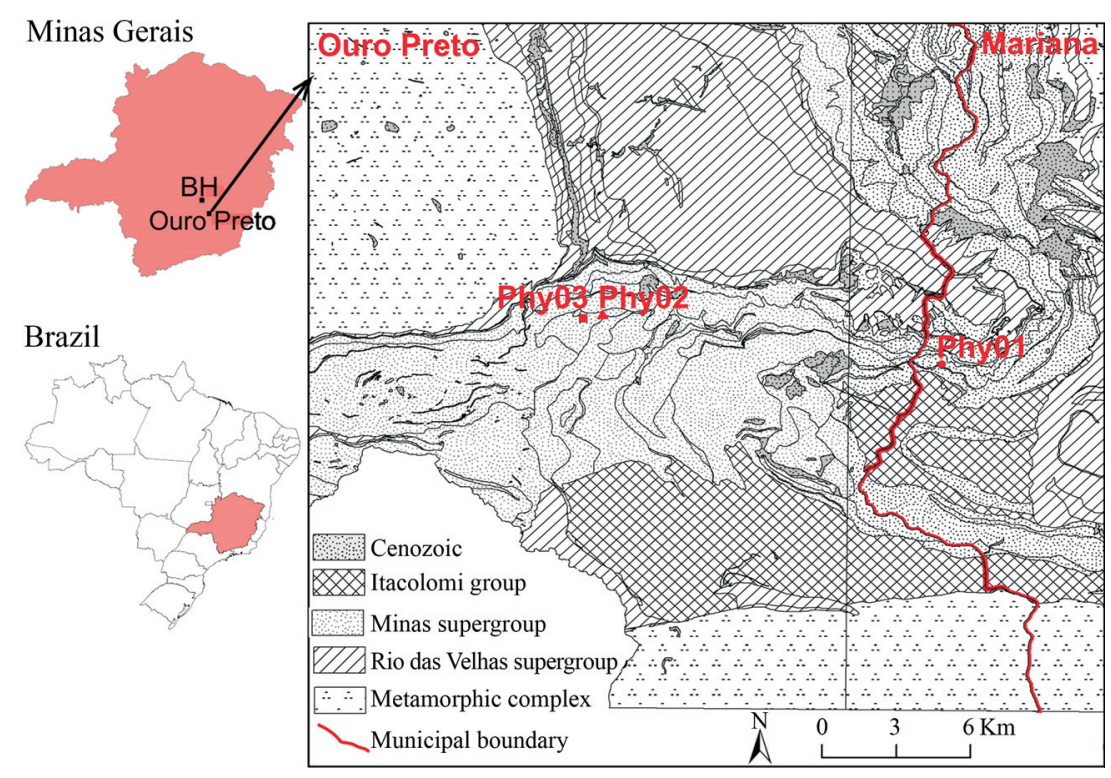

Figure 1 - Geological map with the location of the studied weathering profiles, located in the contiguous cities of Mariana (Phy01) and Ouro Preto (Phy02 and Phy03) (adapted from da Silva et al., 2005; Romano et al., 2017). Ouro Preto is approximately $100 \mathrm{~km}$ from the capital of the State of Minas Gerais (Belo Horizonte, BH), Brazil.

basement, metamorphic complexes of Archean age; Rio das Velhas Supergroup, consisting of an Archean volcanosedimentary sequence (greenstone belt); Minas Supergroup, formed by Proterozoic, metamorphosed, and folded sediments; post-Minas intrusions; Itacolomi Group, consisting of Proterozoic clastic metasediments. As shown in Fig. 1, the studied phyllites belong to the Minas Supergroup.

\section{Methodology}

Phyllite samples at different degrees of weathering were taken from three road slopes located along BR-356 in the state of Minas Gerais, Brazil (Table 1). The degrees of weathering were identified in each profile from the classification proposed by the International Society of Rock Mechanics (ISRM, 2015).

These samples were taken for laboratory tests to obtain physical indices, wave propagation velocity, point load strength index, durability, and mineralogical analysis. It is part of the scope of this paper to present and discuss $V p$ and durability data for materials at different levels of weathering, as well as correlate the properties $V p$ and durability, $V p$ and physical indices, and $V p$ and the point load strength $\left(I s_{(50)}\right)$. Tests were performed according to the suggestions of ISRM (2007).

Listed next are the number of samples used for each weathering class contemplated in this study: 13 from phyllite W1/W2, 19 from phyllite W2, 20 from phyllite W2/W3, 38 from phyllite W3, 23 from phyllite W3/W4, 19 from phyllite W4.

Least-squares regression analyses were applied between $V p$ and durability, $V p$ and physical indices, and $V p$ and $I s_{(50)}$ to verify the possible relationships between these properties. The best-fit line and the correlation coefficients were determined. Different relationships (linear, exponential, logarithmic, and power) were tested in order to obtain the highest correlation coefficient values.

Table 1 - Degrees of weathering of phyllites sampled for laboratory tests. The classification was carried out according to ISRM (2015) guidelines.

\begin{tabular}{llc}
\hline Weathering profiles & Class & Term \\
\hline Phy01 & $\begin{array}{l}\text { Slightly weathered rock } \\
\text { Moderately weathered rock }\end{array}$ & W3 \\
& $\begin{array}{l}\text { Highly weathered rock } \\
\text { Phy02 }\end{array}$ & W4 \\
& $\begin{array}{l}\text { Sound to slightly weathered } \\
\text { rock }\end{array}$ & W1/W2 \\
& $\begin{array}{l}\text { Slightly weathered rock } \\
\text { Slightly weathered to } \\
\text { moderately weathered rock }\end{array}$ & W2 \\
& $\begin{array}{l}\text { Moderately weathered rock } \\
\text { Moderately weathered to }\end{array}$ & W3 \\
& $\begin{array}{l}\text { Wighly weathered rock } \\
\text { Moderately weathered rock }\end{array}$ & W3* \\
& Highly weathered rock & W4 \\
\hline
\end{tabular}

*In the Phy03 profile, three distinct collection points of the moderately altered phyllite (W3) were chosen to evaluate the influence of possible textural and mineralogical differences. 


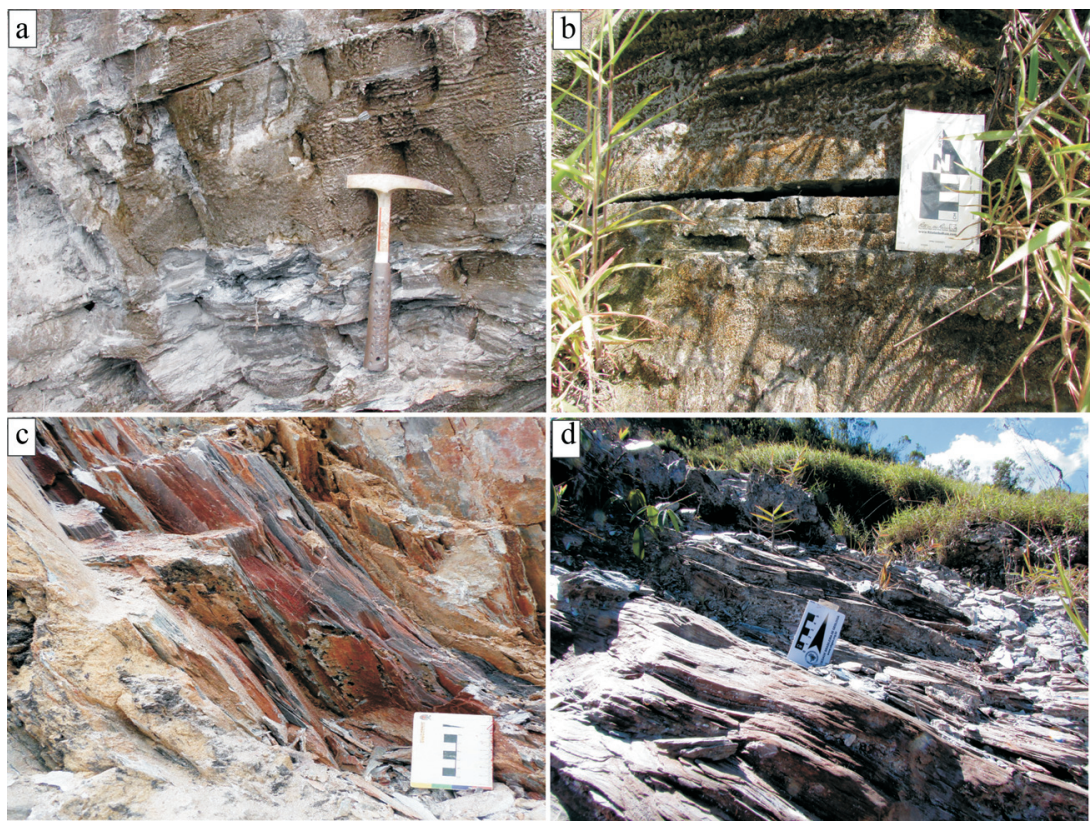

Figure 2 - Outcrops of phyllite W3 (a) and W4 (b) from profile Phy01, W3/W4 from profile Phy02 (c), and W3 from profile Phy03 (d), highlighting discontinuities parallel to foliation resulting from exposure of these rocks to weathering.

\section{Results and Discussions}

\subsection{Main characteristics of the studied phyllites}

The studied phyllites are composed of muscovite, quartz, opaque minerals and chlorite. The main products of weathering on primary minerals are iron oxide/hydroxide and kaolinite. Foliation is penetrative, millimeter-spaced, formed by the alternation of thin micaceous bands, quartzmicaceous bands, and quartz veins. There are also veins consisting of chlorite and opaque minerals, parallel to metamorphic foliation.

One of the main effects of the exposure of these rocks to atmosphere conditions is the formation of fractures parallel to the metamorphic foliation, which intensifies with the advancement of weathering (Fig. 2). There is also increased openness of these discontinuities that become more degraded in the most altered members. This striking characteristic observed in the studied profiles is also noticeable in the petrographic slide due to the presence of microfractures, especially transgranular and intragranular (Fig. 3). As physical weathering is processed, creating preferential spaces for water to enter the rock, opaque minerals are dissolved and iron oxides are precipitated. These results are in agreement with studies carried out in phyllites under tropical (Leão et al., 2017) and subtropical (Marques et al., 2017; Marques et al., 2020; Robert \& Hack, 2020) climates. Figures 4, 5, and 6 show the main implications of weathering on the matrix of this rock.

\subsection{Physical indices}

Dry and saturated apparent specific gravity, apparent porosity, and apparent water absorption capacity are shown in Table 2. Physical parameters are clearly influenced by weathering processes. However, the variation of these parameters is not homogeneous in soil-rock transition materials (W3, W3/W4, and W4). It is mainly due to the increased number of micro-fractures and the widening of pre-existing discontinuities parallel to metamorphic foliation. This increase in porosity with the advancement of weathering is also accompanied by higher precipitation of iron oxide/hydroxide rich solutions, as previously discussed. These characteristics occur most sharply from phyllite W3. Sousa et al. (2005) observed that, unlike what happened in intact or slightly altered granites, the porosity variation was not homogeneous in a very altered granite. This is due, according to the authors, to the action of weathering on micro-fractures, making their performance increasingly complex and reflecting on the physical characteristics of the rock.

\subsection{Durability}

The lowest obtained durability index corresponds to phyllite W3 from profile Phy01 (Table 3). It can be explained by the reduced internal cohesion of its matrix, which was also pointed out by Leão et al. (2017) in altered sericite phyllites from the same site. These phyllites are characterized by levels of mafic and siliceous minerals that fill foliation (Fig. 4). Leão (2017) performed durability studies on phyllites located in profile Phy01 and obtained nonlinear behavior of $I_{d 2}$ values among phyllites with different degrees of weathering. The author attributed this behavior to the presence of cemented levels, whose origin would not be the result of the weathering action. These levels are unevenly distributed throughout the profile, causing heterogeneities in the rock. Thus, the conclusion reached 


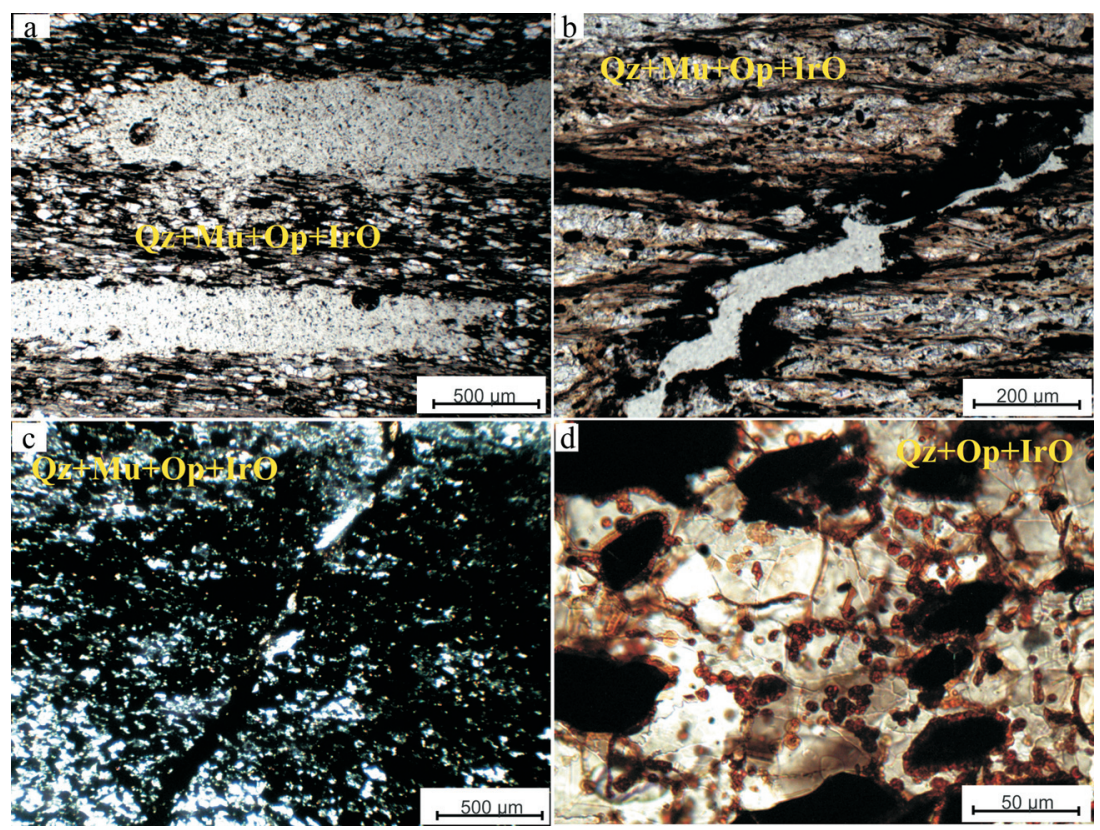

Figure 3 - Textural and mineralogical aspects of phyllites in petrographic slides. Slides are from samples collected from profile Phy03. The abbreviation means: IrO iron oxides/hydroxides; Mu muscovite; $O p$ Opaque; $Q z$ quartz. In (a) there is a fracture parallel to metamorphic foliation (phyllite W3). In (b and c) there is a transgranular fracture and precipitation of iron oxides/hydroxides due to the weathering of opaque (phyllite W3 and W4, respectively). In (d) there is a precipitation of iron oxides/hydroxides in the matrix and intragranular fractures of quartz grains (phyllite W3).
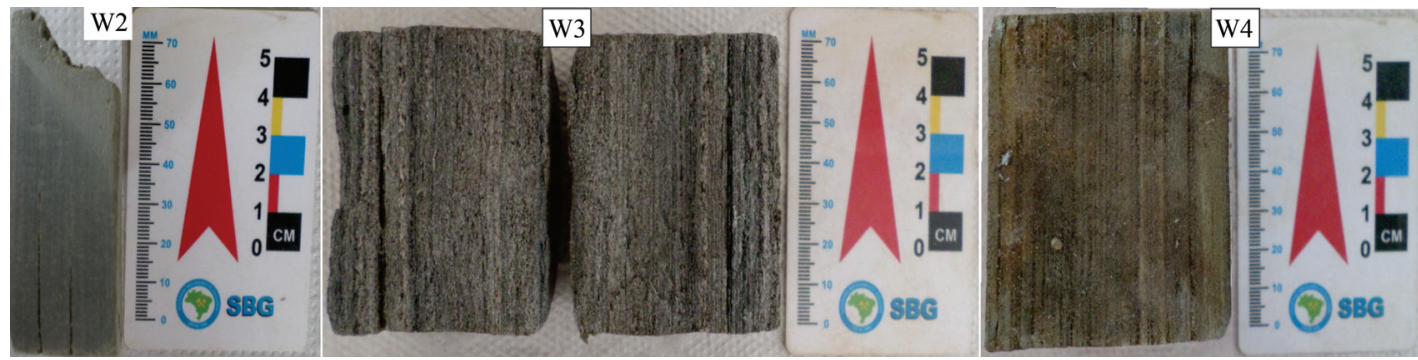

Figure 4 - Aspects of the phyllite matrix at different degrees of weathering of profile Phy01. Scale in centimeters (cm). SBG - Brazilian Geological Society.

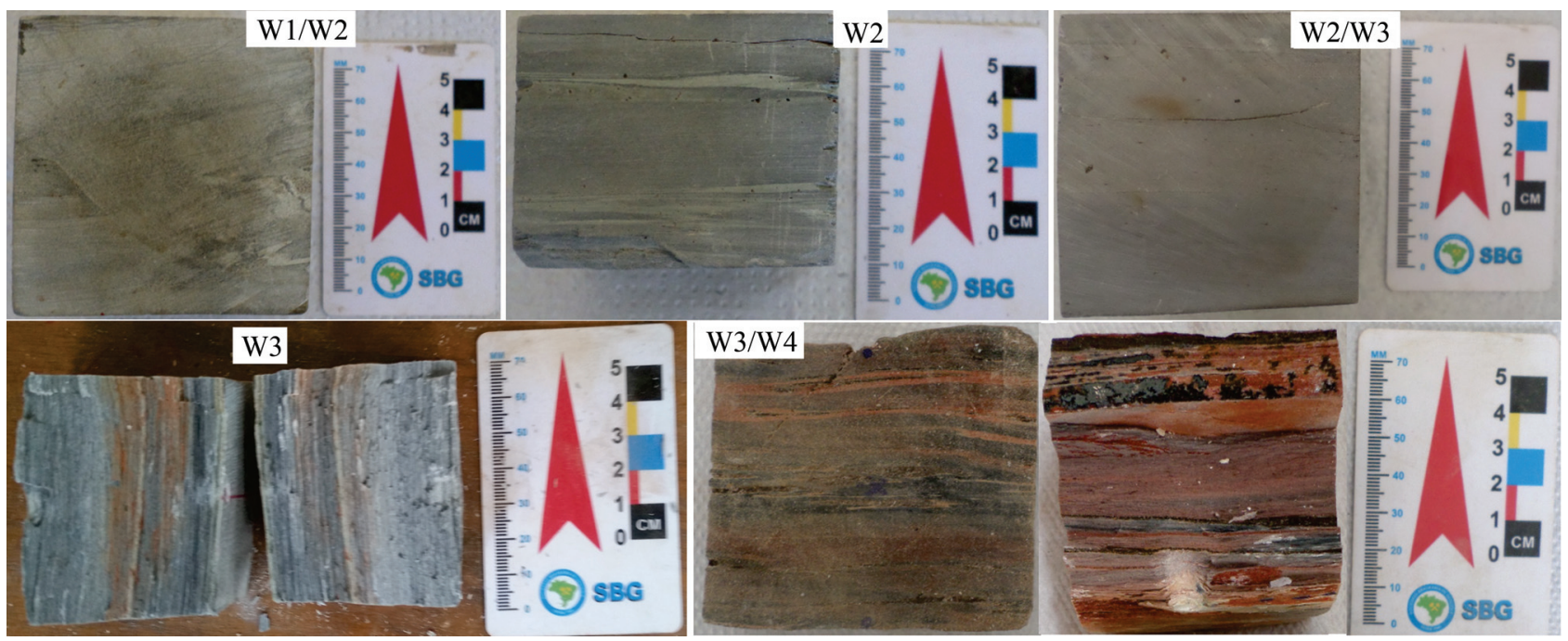

Figure 5 - Aspects of the phyllite matrix at different degrees of weathering of profile Phy02. Scale in centimeters (cm). SBG - Brazilian Geological Society. 
by this author is in agreement with the results from the present study, as these same levels were also identified in this research, which would explain the increase in durability found in phyllite $\mathrm{W} 4$ in relation to $\mathrm{W} 3$ from profile Phy01.

In profile Phy02, $I_{d 2}$ values obtained for slightly altered phyllites (W1/W2, W2, and W2/W3) are above $90 \%$.
Similar values were found by Ramamurthy et al. (1993) (97.56\% for intact micaceous phyllites), Andrade \& Saraiva (2010) (90.7 to $98.9 \%$ for phyllites W1 and W2), Marques et al. (2010) (durability values higher than $95 \%$ for gneisses W1 and W2), and Silva \& Lana (2012) (90.36 to $91.56 \%$ for sericite phyllites W2).

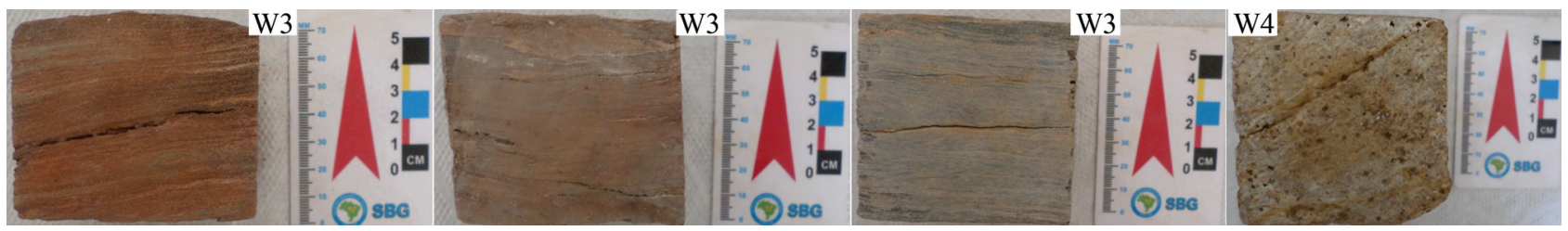

Figure 6 - Aspects of the matrix of weathered phyllites of profile Phy03. Samples of phyllite W3 were collected from three different points of the profile, demonstrating the heterogeneity of the rock. Scale in centimeters (cm). SBG - Brazilian Geological Society.

Table 2 - Mean (M) and standard deviation (SD) of values of dry $\left(\rho_{d r y}\right)$ and saturated $\left(\rho_{s a t}\right)$ apparent specific gravity, apparent porosity $(\eta)$, and apparent water absorption ( $a b s)$ for different classes of phyllite weathering of the three weathering profiles.

\begin{tabular}{|c|c|c|c|c|c|c|c|c|c|}
\hline & Class & $\rho_{d r y}\left(\mathrm{~g} / \mathrm{cm}^{3}\right)$ & $\mathrm{SD}\left(\mathrm{g} / \mathrm{cm}^{3}\right)$ & $\rho_{\text {sat }}\left(\mathrm{g} / \mathrm{cm}^{3}\right)$ & $\mathrm{SD}\left(\mathrm{g} / \mathrm{cm}^{3}\right)$ & $\eta(\%)$ & $\mathrm{SD}(\%)$ & $a b s(\%)$ & $\mathrm{SD}(\%)$ \\
\hline \multirow[t]{3}{*}{ Phy01 } & $\mathrm{W} 2$ & 2.79 & 0.03 & 2.85 & 0.03 & 6.06 & 0.25 & 2.18 & 0.11 \\
\hline & W3 & 2.38 & $\mathrm{ND} *$ & 2.53 & ND & 14.29 & ND & 6.00 & ND \\
\hline & W4 & 1.95 & ND & 2.09 & ND & 14.07 & ND & 7.23 & ND \\
\hline \multirow[t]{5}{*}{ Phy02 } & W1/W2 & 2.8 & 0.01 & 2.84 & 0.01 & 4.17 & 0.19 & 1.49 & 0.07 \\
\hline & W2 & 2.72 & 0.02 & 2.78 & 0.02 & 6.14 & 0.43 & 2.26 & 0.17 \\
\hline & W2/W3 & 2.75 & 0.05 & 2.83 & 0.04 & 8.57 & 0.29 & 3.12 & 0.16 \\
\hline & W3 & 2.44 & 0.03 & 2.59 & 0.03 & 14.89 & 0.52 & 6.09 & 0.29 \\
\hline & W3/W4 & 2.14 & 0.14 & 2.36 & 0.10 & 22.00 & 4.11 & 10.35 & 2.59 \\
\hline \multirow[t]{4}{*}{ Phy03 } & W3 & 2.38 & 0.03 & 2.54 & 0.01 & 15.76 & 1.60 & 6.63 & 0.75 \\
\hline & W3 & 2.30 & 0.06 & 2.48 & 0.04 & 17.99 & 1.76 & 7.84 & 0.98 \\
\hline & W3 & 2.40 & 0.09 & 2.55 & 0.07 & 15.12 & 2.26 & 6.32 & 1.18 \\
\hline & W4 & 2.37 & 0.07 & 2.54 & 0.05 & 16.20 & 2.17 & 6.84 & 1.11 \\
\hline
\end{tabular}

*ND Not determined.

Table 3 - Durability index $\left(I_{d 1}\right.$ and $\left.I_{d 2}\right)$ and wave propagation velocity $(V p)$ of phyllites at different states of alteration of the three weathering profiles.

\begin{tabular}{lccccc}
\hline Weathering profiles & Class & $I_{d 1}(\%)$ & $I_{d 2}(\%)$ & $V p$ perpendicular direction $(\mathrm{m} / \mathrm{s})$ & $V p$ parallel direction $(\mathrm{m} / \mathrm{s})$ \\
\hline Phy01 & W2 & 88.19 & 76.76 & 445.14 & 4795.00 \\
& W3 & 8.19 & 1.66 & 126.00 & 3474.25 \\
& W4 & 11.67 & 7.44 & ND* & ND \\
Phy02 & W1/W2 & 98.18 & 96.82 & 2040.10 & 5382.42 \\
& W2 & 97.32 & 95.52 & 969.71 & 4601.33 \\
& W2/W3 & 95.18 & 91.75 & 1011.42 & 4716.65 \\
& W3 & 95.49 & 91.81 & 742.00 & 4243.79 \\
Phy 3 & W3/W4 & 76.47 & 60.34 & 501.92 & 4415.32 \\
& W3 & 61.34 & 44.08 & 394.67 & 4011.83 \\
& W3 & 85.51 & 73.83 & 366.00 & 3802.14 \\
& W3 & 71.94 & 55.05 & 523.43 & 3830.78 \\
\end{tabular}

*ND Not determined. 
The durability obtained from phyllites $\mathrm{W} 3$ is quite variable. Except for phyllite W3 from profile Phy01, which has a very low internal cohesion (a characteristic of this profile), $I_{d 2}$ ranged from 91.81 (profile Phy02) to $44.08 \%$ (profile Phy03). High variations in moderately weathered phyllites were also reported by Andrade \& Saraiva (2010) (between 59.6 and $98.2 \%$ ) and Silva \& Lana (2012) (between 86.18 and $54.32 \%$ ).

The variation in durability found for phyllites W3 may be related to the following changes imposed by weathering, which increase significantly in this degree of alteration: increase in pore volume and significant presence of altered opaque minerals, i.e., which had their crystalline form modified (Fig. 3d). Similarly to the present study, Dhakal et al. (2002) found a close relationship between durability and weathering in clastic rocks since it provided changes in pore volume and distribution and caused crystalline changes in smectites, which coincides with the results of the present study.

Graphs of Figs. 7 and 8 compare the average values of $I_{d 2}$ and porosity and $I_{d 2}$ and amount of oxides, respectively, in the different weathering classes, being possible to observe the influence of these factors on durability. The increased porosity, associated with permeability, provides a larger surface area of the rock available for contact with water (specific surface), which acts to decrease durability, by weakening chemical bonds, changing properties of mineral constituents and causing instability along weakness planes due to pore water pressure (Koncagül \& Santi, 1999).

Figures 9 and 10 show, respectively, $I_{d 2}$ values with weathering progression and phyllite samples after being subjected to two wetting and drying cycles. As can be observed, although $I_{d 2}$ does not uniformly follow the evolution of the alteration, there is a general trend to reduce this parameter with weathering.

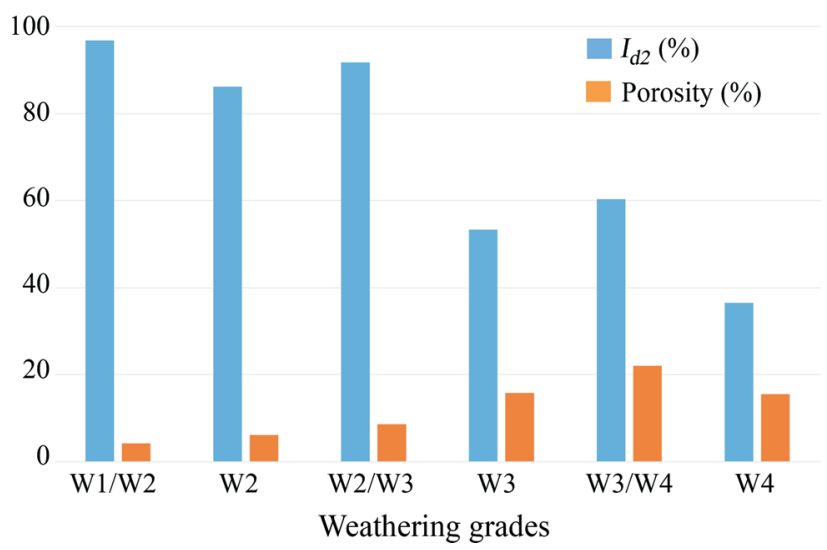

Figure 7 - Mean values of $I_{d 2}$ and porosity of each weathering class. A more significant reduction in durability is observed as there is a more significant increase in porosity from the moderately altered phyllite (W3).

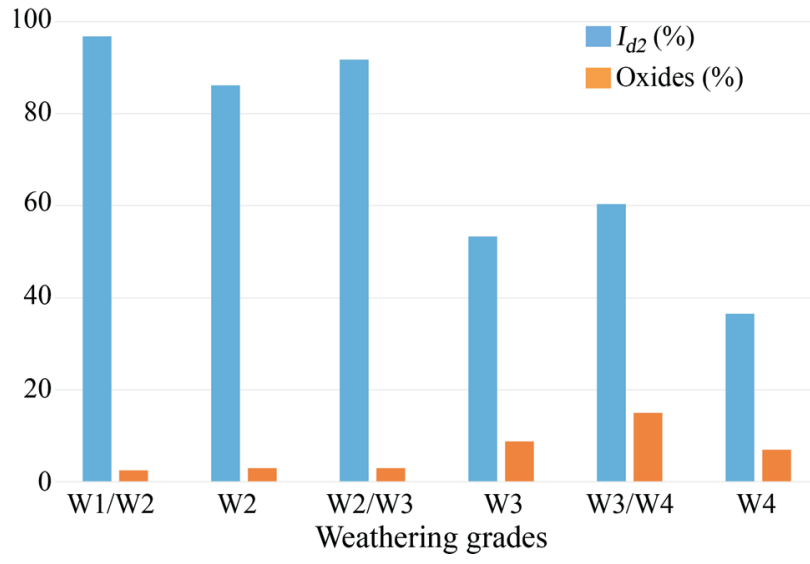

Figure 8 - Mean values of $I_{d 2}$ and oxide concentration of each weathering class. There is a more marked decrease in durability while a more significant increase in oxide precipitation from the moderately weathered phyllite (W3). Elevated oxide concentration indicates a higher alteration in opaque minerals.

The variability found in durability between phyllites of the same alteration class is also attributed to the heterogeneity of the rock, including the same profile. It happened, for instance, in phyllites W3 collected at distinct points in profile Phy03 (Fig. 2). Depending on profile position, the rock may contain more or less opaque and hence, oxide content, as well as variations in quartz content. Thus, durability is influenced not only by secondary processes derived from weathering but also by the heterogeneity itself intrinsic to the mineralogical composition variation of these phyllites.

\subsection{Wave propagation velocity}

Some samples showed no detection of $V p$ signal measured perpendicularly to foliation, while in others (the majority), the intensity signal detected during tests was very low, rarely $100 \%$. The attenuation of $V p$ in the perpendicular direction is caused by the presence of fractures parallel to foliation that make the rock discontinuous, affecting it significantly. There are often reports in the literature of dif-

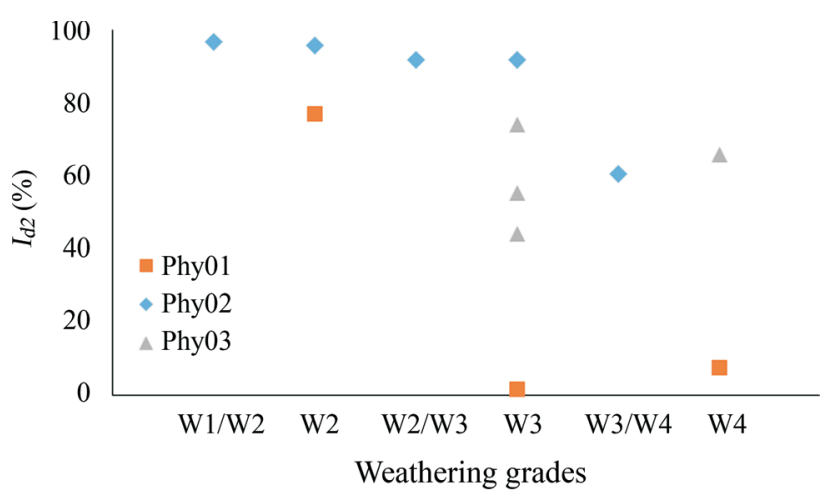

Figure 9 - Relationship between $I_{d 2}$ and different degrees of alteration of phyllite samples collected in three distinct weathering profiles (Phy01, Phy02, and Phy03). 


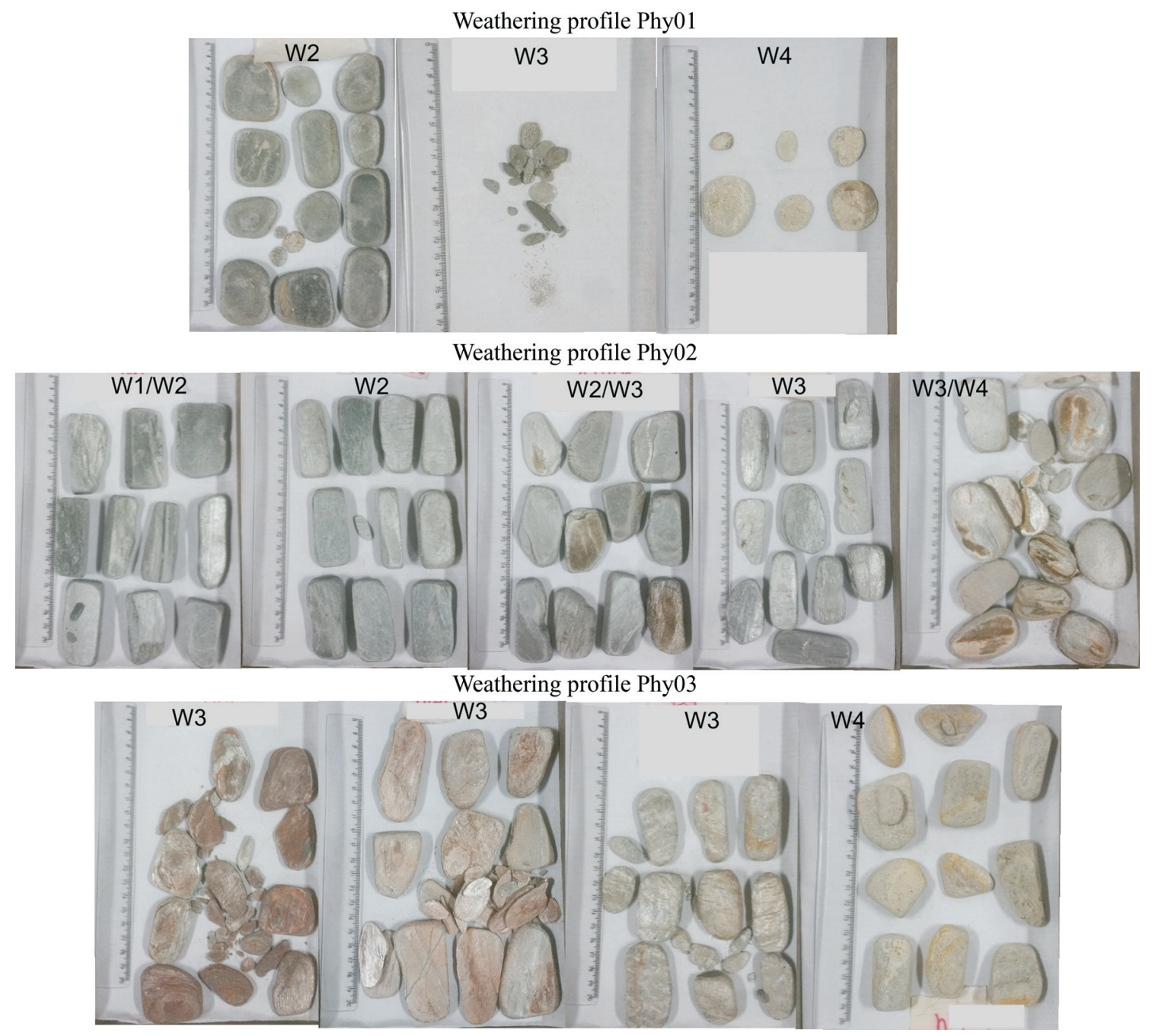

Figure 10 - Results of samples of altered phyllites after two wetting and drying cycles.

ferences in $V p$ in the direction perpendicular and parallel to foliation in rocks with anisotropic properties (Ramamurthy et al., 1993; Marques et al., 2010; Kurtulus et al., 2012; Nikrouz et al., 2016). Jensen \& Elming (2013) reported as potential causes of seismic anisotropy the micro-fissures, joints, faults, macroscopic foliation, stratification, and weathering. These authors found anisotropy in $V p$ in metariolites with microfoliation, obtaining the highest values in the direction parallel to it.

The values of $V p$ obtained in the parallel direction for slightly altered phyllites (W1/W2, W2, and W2/W3) are in the range of 4601.33-5382.42 (m/s), being compatible with the results of phyllites with similar mineralogical composition considered intact or little altered by other researchers (Ramamurthy et al., 1993; Andrade \& Saraiva, 2010).

As shown in Fig. 11, moderately to very altered phyllites (W3, W3/W4, and W4) transmit the ultrasonic waves with less efficiency. $V p$ is sensitive to the state of alteration of the studied rocks, showing a general trend of reduction as weathering increases.

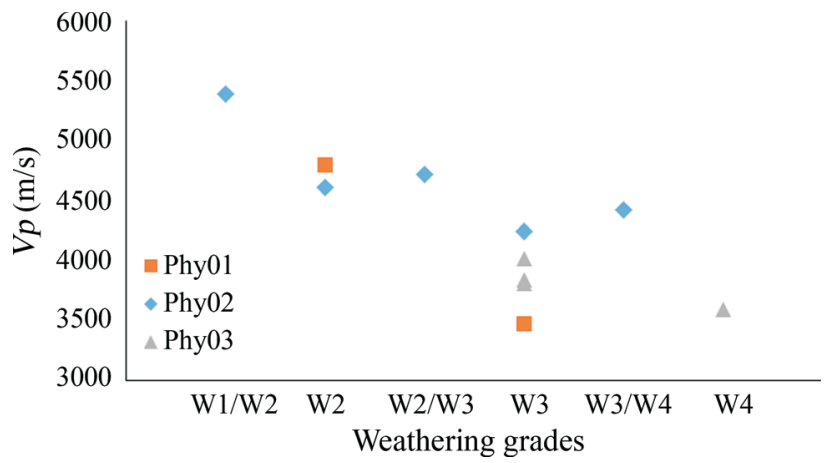

Figure 11 - Relationship between the velocity of ultrasonic wave propagation measured parallel to foliation and the degree of alteration of phyllite samples collected in three weathering profiles (Phy01, Phy02, and Phy03). 


\subsection{Correlations}

\subsubsection{Correlation between $I_{d 1}$ and $I_{d 2}$ with $V p$}

The values of $V p$ measured in the direction perpendicular to foliation were not considered, due to the low intensity signal detected during tests.

Figure 12 shows the correlations between $I_{d 1}$ and $V p$ and $I_{d 2}$ and $V p$. In Figs. 12a and 12b, correlations were performed between the mean values of each alteration class, while in Figs. 12c and 12d, the individual values were used, obtaining a much lower correlation coefficient. The dispersed values shown in Figs. 12c and 12d are the result of the influence of weathering and anisotropy of the studied phyllites.

Based on the obtained results, the use of mean values was adequate to correlate durability and wave propagation velocity. Khandelwal (2013) obtained a good correlation between $V p$ and $I_{d 1}$ for different rock types, including shales, for $V p$ values in the range from 1682 to $4657 \mathrm{~m} / \mathrm{s}$. Sharma \& Singh (2008) also found a good correlation between these two parameters when evaluating seven different types of rock, including phyllites and shales.

\subsubsection{Correlation between Vp and physical indices}

Figure 13 shows that all the physical indices have a strong relationship with $V p$, with a reduction in $V p$ as density decreases (increased porosity and water absorption). These results are in agreement with Gaviglio (1989), Tur-
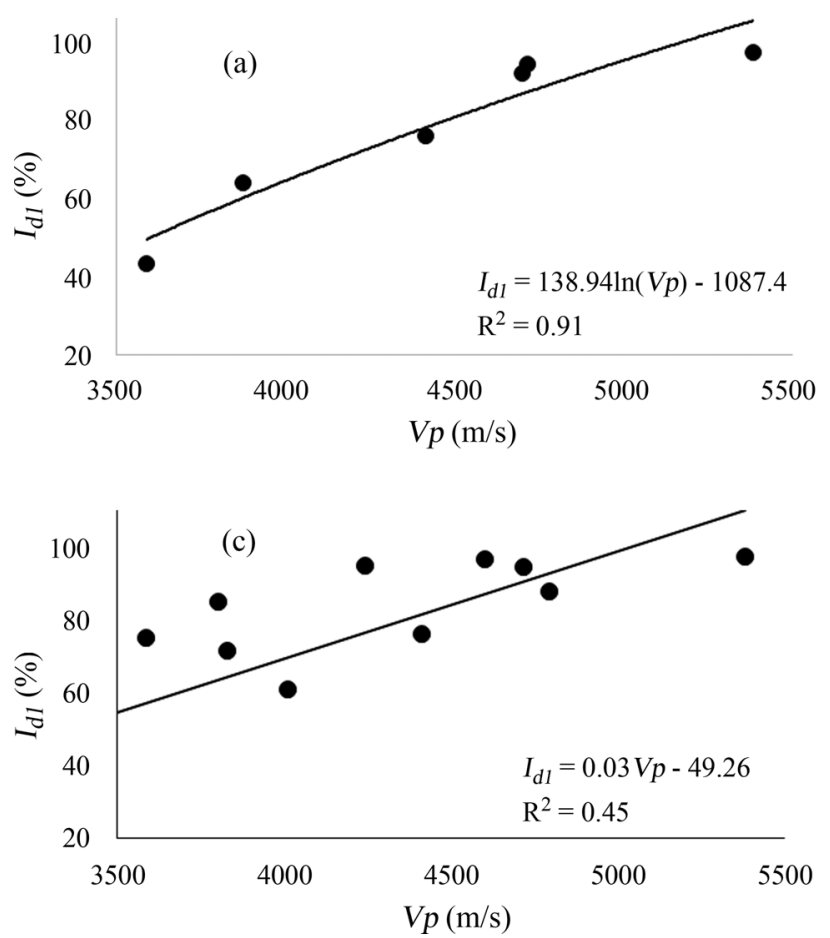

grul \& Zarif (1999), Yasar \& Erdogan (2004), Kurtulus et al. (2010), Diamantis et al. (2011), Sarkar et al. (2012), Khandelwal (2013), and Azimian \& Ajalloeian (2015), who studied the relationship between physical properties and $\mathrm{Vp}$ and obtained good correlations between these parameters.

\subsubsection{Correlations between Vp and Is}

Graphs in Fig. 14 show the relationship between $V p$ and $I s_{(50)}$. As expected, the lower the $I s_{(50)}$ is, the lower the $V p$. There is a good relationship between $V p$ and $I s_{(50)}$ measured perpendicular to foliation, with a correlation coefficient of 0.7779 (Table 4), while the correlation coefficient between $V p$ and $I s_{(50)}$ measured parallel to foliation is lower $\left(\mathrm{R}^{2}=0.6139\right)$, unlike expected. Thus, despite showing influence on $V p$ and $I s_{(50)}$, metamorphic foliation is not sufficient to explain the good relationship obtained between these properties.

On the other hand, porosity is closely related to $V p$ (Fig. 13) and influences the resistance of weathered rocks (Marques et al., 2010; Andrade \& Saraiva, 2010; Leão et al., 2017) since the presence of pores makes the rock less continuous, decreasing $V p$ and increasing the fragility of the matrix when subjected to compression (Sousa et al., 2005). Thus, the increased porosity due to weathering processes may play a preponderant role in the variation of these properties ( $V p$ and $\left.I s_{(50)}\right)$ in the studied phyllites.
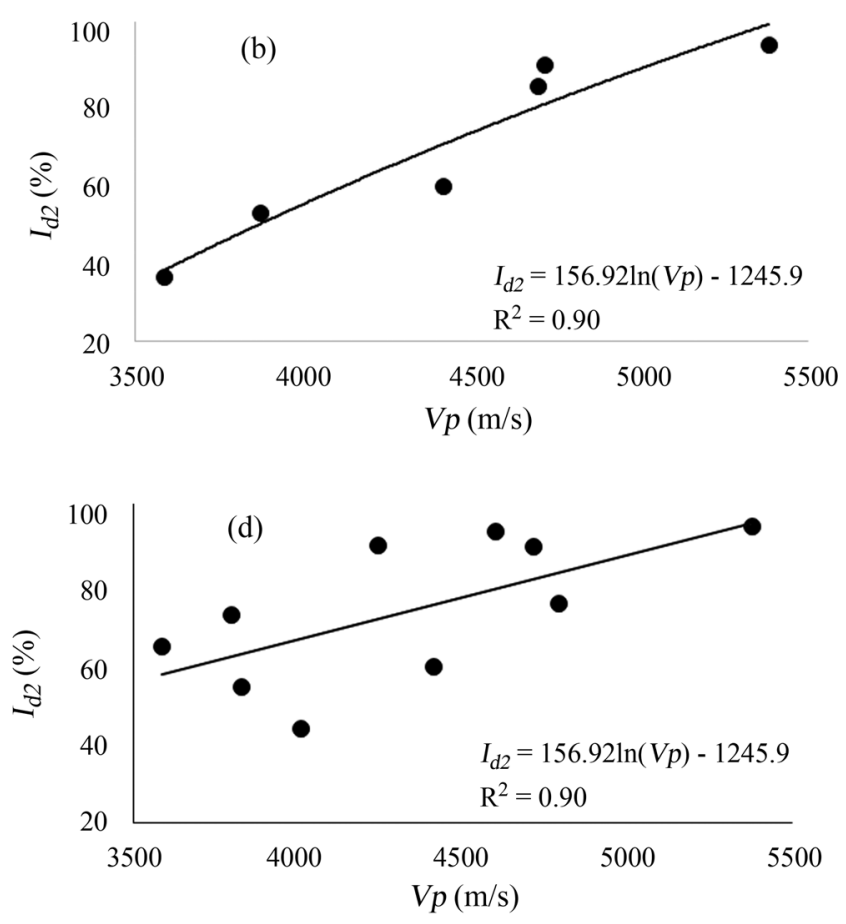

Figure 12 - Correlations between $I_{d 1}$ and $V p$ (parallel to foliation) and $I_{d 2}$ and $V p$ (parallel to foliation). In (a) and (b), correlation between the mean values of each alteration class. In (c) and (d), correlation between the values obtained from all weathering grades of the three studied profiles. 

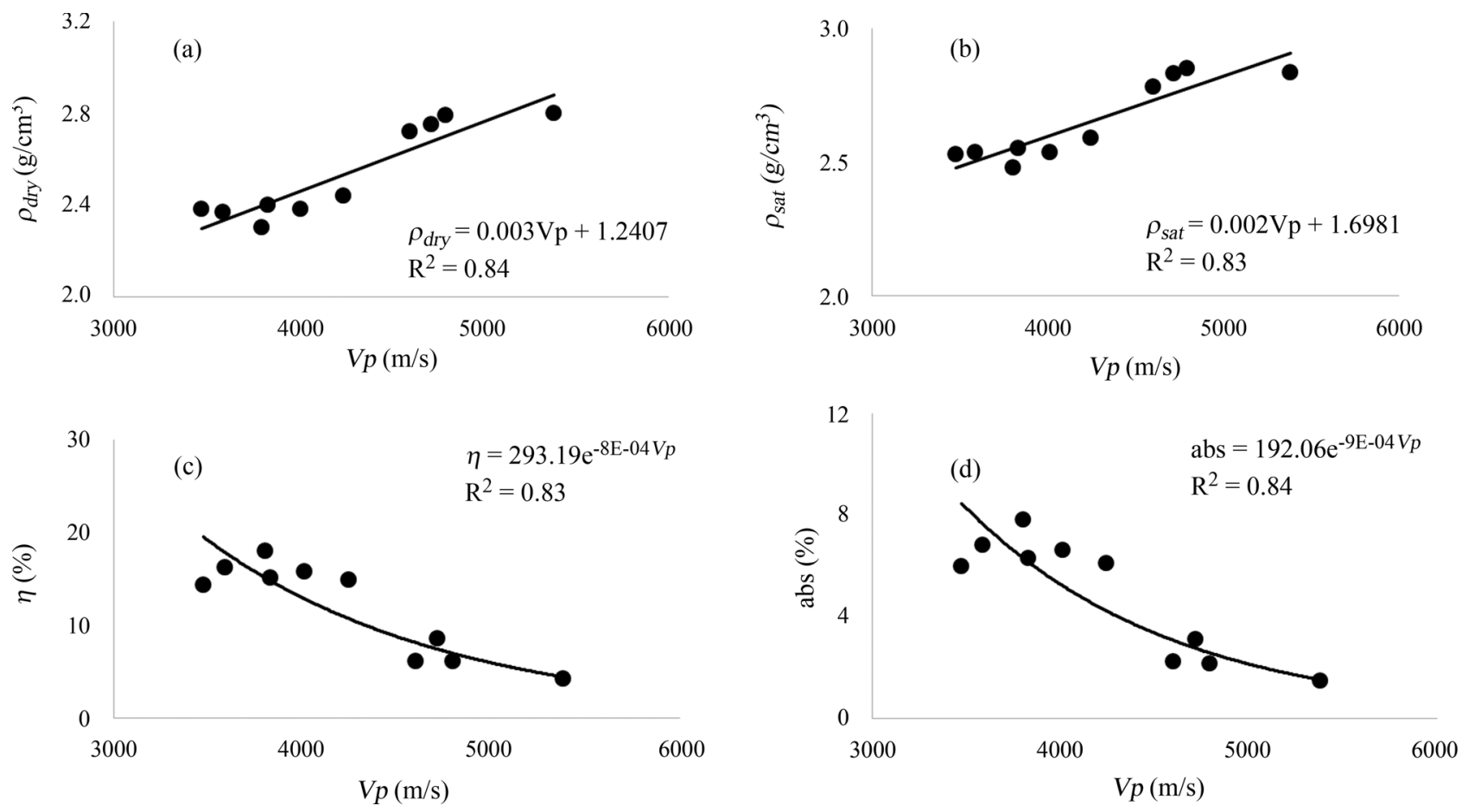

Figure 13 - Correlations between $V p$ (parallel to foliation) and physical indices: dry (a) and saturated apparent specific gravity (b), porosity (c), and water absorption capacity (d).

Table 4 - Equations correlating $V p$ (parallel to foliation) and $I s_{(50)}$ in different types of rock.

\begin{tabular}{lccc}
\hline Equations & Correlation coefficient & References & Rock \\
\hline$I s_{(50)}=6.67 \ln (V p)-51.9$ & 0.93 & Jamshidi et al. $(2016)$ & Travertine \\
$I s_{(50)}=0.0018(V p)-1.9906$ & 0.95 & Kurtulus et al. $(2010)$ & Andesites \\
$I s_{(50)}=0.0042(V p)-14.602$ & 0.90 & Kurtulus et al. $(2012)$ & Serpentine ultrabasic rocks \\
$V p=-16.784 I s_{(50)}+6078.9$ & 0.55 & Jensen \&Elming $(2013)$ & Meta-riolites \\
$V p=859.02 I s_{(50)}{ }^{\mathrm{a}}+3475.2$ & 0.78 & Present study & Phyllite \\
$V p=3155.9 I s_{(50)}{ }^{\mathrm{b}}+3574.1$ & 0.61 & Present study & Phyllite \\
\hline
\end{tabular}

$I s_{(50)}{ }^{a}$ Direction of loading perpendicular to foliation.

$I s_{(50)}{ }^{\mathrm{b}}$ Direction of loading parallel to foliation.
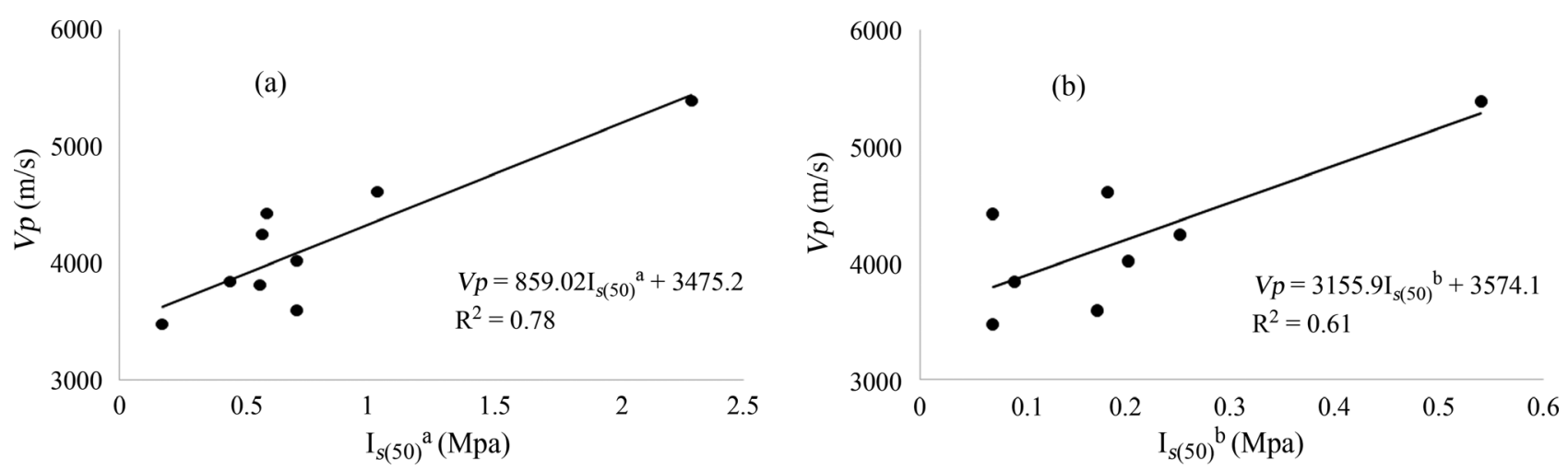

Figure 14 - Relationship between $V p$ (parallel to foliation) and $I s_{(50)}$ perpendicular to foliation $\left(I s_{(50)}{ }^{\mathrm{a}}\right)$ and parallel to foliation $\left(I s_{(50)}{ }^{\mathrm{b}}\right)$. 


\section{Conclusions}

The slake durability test performed in the studied phyllites showed that weathering has a clear influence on this geotechnical property, affecting the texture and mineralogical composition of these rocks. As expected, the progressive increase in porosity and mineral alteration due to weathering was accompanied by a reduction in durability, but the intensity in which this process occurs was established.

$V p$ decrease with weathering is closely related to variation of physical indices, as proved by the significant correlation coefficients found. Intact rock strength and $V p$ are influenced by metamorphic foliation. Also, the very good correlation found between $V p$ and $\mathrm{Is}_{(50)}$ may be influenced by the effects of weathering, which cause a higher increase in porosity when compared to the anisotropy intrinsic to phyllites resulting from mineral alignment.

$V p$ and durability, although presenting general trends, do not evolve uniformly with the weathering progression since porosity, the main physical parameter that influences strength has heterogeneous behavior. This behavior attributed to porosity is probably associated with physical weathering, due to the increase in spacing of pre-existing discontinuities and formation of a micro-fracture network. Therefore, the action of weathering on fractures and micro-fractures makes their effects increasingly complex, reflecting on the physical characteristics of the rock.

In addition to the influence of secondary weathering processes on the variability of physical and mechanical parameters, there is also the mineralogical heterogeneity intrinsic to these phyllites, observed between samples with the same degree of alteration in the same profile, but taken from different points. Both heterogeneity and anisotropy are also revealed in the correlation established between $V p$ and $I_{d 1}$ and $V p$ and $I_{d 2}$ when all values for each sample from all three slopes are incorporated. The use of mean values of each alteration class improves the correlation between these properties and allows concluding that the evaluated physical parameters should be used prudently in geotechnical projects, being important that they are associated with a field control, contemplating descriptions of the rocky massif (including discontinuity characteristics), petrographic and micropetrographic analyses, as well as other types of physical and mechanical tests.

Good correlations were found for $V p$ and slake durability index, for $V p$ and all physical indices, and for $V p$ and point load strength measured perpendicular to foliation.

Finally, the authors suggest that similar studies, with the same tests/analyses, should be performed on similar rock types (and also with other lithotypes) from other regions from Brazil.

\section{Acknowledgments}

Authors thank Fundação de Amparo à Pesquisa do Estado de Minas Gerais (FAPEMIG) (Process APQ-
01143-16) for granting funding and Universidade Federal de Viçosa -Brazil, for funding and providing laboratory support for the laboratory tests.

\section{References}

Alkmim, F.F. \& Marshak, S. (1998). Transmazonian orogeny in the southern São Francisco Craton region, Minas Gerais, Brazil: Evidence for paleoproterozoic collision and collapse in the Quadrilátero Ferrífero. Precambrian Research, 90(1-2):29-58. DOI 10.1016/S0301-9268(98)00032-1

Andrade, P.S. \& Saraiva, A.A. (2010). Physical and mechanical characterization of phyllites and metagreywackes in central Portugal. Bull. Eng. Geol. Env., 69(2):207-214. DOI 10.1007/s10064-009-0251-9

Azimian, A. \& Ajalloeian, R. (2015). Empirical correlation of physical and mechanical properties of marly rocks with P-wave velocity. Arab. J. Geosci., 8:2069-2079. DOI 10.1007/s12517-013-1235-4

Cetin, H.; Laman, M. \& Ertune, A. (2000). Settlement and slaking problems in the world's fourth largest rock-fill dam, the Ataturk Dam in Turkey. Eng. Geol., 56(3-4):225-242.

DOI 10.1016/S0013-7952(99)00049-6

Çobanoglu, I. \& Çelik, S.B. (2008). Estimation of uniaxial compressive strength from point load strength, Schmidt hardness and P-wave velocity. Bull. Eng. Geol. Env., 67:491-498. DOI 10.1007/s10064-008-0158-x

Crosta, G. (1998). Slake durability Vs ultrasonic treatment for rock durability determinations. Int. J. Rock. Mech. Min. Sci., 35(6):815-824

Dhakal, G.; Yoneda, T.; Kato, M. \& Kaneko, K. (2002). Slake durability and mineralogical properties of some pyroclastic and sedimentary rocks. Eng. Geol., 65(1):31-45 DOI 10.1016/S0013-7952(01)00101-6

Diamantis, K.; Bellas, S.; Migiros, G. \& Gartzos, E. (2011). Correlating wave velocities with physical, mechanical properties and petrographic characteristics of peridotites from the Central Greece. Geotech. Geol. Eng., 29:1049-1062. DOI 10.1007/s10706-011-9436-7

Franklin, J.A. \& Chandra, R. (1972). The slake durability test. Int. J. Rock. Mech. Min. Sci., 9(3):325-341. DOI 10.1016/0148-9062(72)90001-0

Gardner, G.H.F.; Gardner, L.W. \& Gregory, A.R. (1974). Formation velocity and density: the diagnostic basis for stratigraphy. Geophysics, 39(6):770-780. DOI 10.1190/1.1440465

Gaviglio, P. (1989). Longitudinal wave propagation in a limestone: the relationship between velocity and density. Rock Mech. Rock Eng., 22:299-306. DOI 10.1007/BF01262285

Gupta, V. \& Ahmed, I. (2007). The effect of $\mathrm{pH}$ of water and mineralogical properties on the slake durability (degradability) of different rocks from the Lesser Hima- 
laya, India. Eng. Geol., 95(3-4):79-87. DOI 10.1016/j.enggeo.2007.09.004

ISRM (2007). The Complete ISRM Suggested Methods for Rock Characterization, Testing and Monitoring: 19742006. ISRM, Springer, Cham, 628 p.

ISRM (2015). The IRSM Suggested Methods for Rock Characterization, Testing and Monitoring: 2007-2014. ISRM, Springer, Cham, 293 p.

Jamshidi, A.; Nikudel, M.R.; Khamehchiyan, M.; Sahamieh, R.Z. \& Abdi, Y. (2016). A correlation between P-wave velocity and Schmidt hardness with mechanical properties of travertine building stones. Arab. J. Geosci., 9:568. DOI 10.1007/s12517-016-2542-3

Jensen, M.B. \& Elming, S.Å. (2013). Magnetic, seismic and mechanical properties of porphyritic meta-rhyolites - The effect of microscopic foliation on rock strength and P-wave velocity in drill cores. Eng. Geol., 157(8):93-102. DOI 10.1016/j.enggeo.2013.01.008

Kahraman, S. (2001). A correlation between P-wave velocity, number of joints and Schmidt hammer rebound number. Int. J. Rock Mech. Min. Sci., 38:729-733. DOI 10.1016/S1365-1609(01)00034-X

Kanji, M. \& Leão, M. F. (2020). Correlation of soft rock properties. Kanji, M.; He, M. \& Sousa, L.R. (eds), Soft Rock Mechanics and Engineering. Springer, Switzerland, pp. 407-423. DOI 10.1007/978-3-030-29477-9

Khandelwal, M. (2013). Correlating P-wave velocity with the physico-mechanical properties of different rocks. Pure Appl. Geophys., 170:507-514. DOI 10.1007/s00024-012-0556-7

Koncagül, E.C. \& Santi, P.M. (1999). Predicting the unconfined compressive strength of the Breathitt shale using slake durability, shore hardness and rock structural properties. Int. J. Rock Mech. Min. Sci., 36(2):139-153. DOI 10.1016/S0148-9062(98)00174-0

Kurtulus, C.; Bozkurt, A. \& Endes, H. (2012). Physical and mechanical properties of serpentinized ultrabasic rocks in NW Turkey. Pure Appl. Geophys., 169:1205-1215. DOI 10.1007/s00024-011-0394-Z

Kurtulus, C.; Serkan Irmak, T. \& Sertçelik, I. (2010). Physical and mechanical properties of Gokceada: Imbros (NE Aegean Sea) Island andesites. Bull. Eng. Geol. Environ., 69:321-324. DOI 10.1007/s10064-010-0270-6

Leão, M.F.; Barroso, E.V.; Polivanovi, H.; Marques, E.A.G. \& Vargas Jr, E.A. (2017). Weathering of metapelites from the Quadrilátero Ferrífero mineral province, southeastern Brazil. Bull. Eng. Geol. Env., 78(1):19-33. DOI 10.1007/s10064-017-1036-1

Leão, M.F. (2017). Geomechanical Behavior of Weathering Front in Filito of the Quadrilátero Ferrífero Region. Ph.D. Thesis, Department of Geology, Federal University of Rio de Janeiro, Rio de Janeiro, 186 p. (in Portuguese)

Ioanna, I.; Dimitrios, R.; Theodora, P. \& Paris, T. (2009). Geotechnical and mineralogical properties of weak rocks from Central Greece. Cent. Eur. J. Geosci., 1:431-442. DOI 10.2478/v10085-009-0029-0

Marques, E.A.G.; Barroso, E.V.; Menezes Filho, A.P. \& Vargas JR, E.A. (2010). Weathering zones on metamorphic rocks from Rio de Janeiro - Physical, mineralogical and geomechanical characterization. Eng. Geol., 111(1-4):1-18. DOI 10.1016/j.enggeo.2009.11.001

Marques, E.A.G.; Williams, D.J.; Assis, I.R. \& Leão, M.F. (2017). Effects of weathering on characteristics of rocks in a subtropical climate: weathering morphology, in situ, laboratory and mineralogical characterization. Environ. Earth Sci., 76:602. DOI 10.1007/s12665-017-6936-7

Marques, E.A.G.; Vargas Jr., E.A. \& Leão, M.F. (2020). Weathering of rocks in Brazil. Kanji, M.; He, M. \& Sousa, L.R. (eds), Soft Rock Mechanics and Engineering. Springer, Switzerland, pp. 251-291.

Nefeslioglu, H.A. (2013). Evaluation of geo-mechanical properties of very weak and weak rock materials by using non-destructive techniques: Ultrasonic pulse velocity measurements and reflectance spectroscopy. Eng. Geol., 160:8-20. DOI 10.1016/j.enggeo.2013.03.023

Nikrouz, R.; Moomivand, H. \& Azad, R. (2016). Effect of foliation orientation on the $\mathrm{P}$ - and S-wave velocity anisotropies and dynamic elastic constants of the quartz-micaschists metamorphic rocks, Angouran mine, Iran. Arab. J. Geosci., 9:1-9. DOI 10.1007/s12517-016-2699-9

Ramamurthy, T.; Rao, G.V. \& Singh, J. (1993). Engineering behavior of phyllites. Eng. Geol., 33(3):209-225. DOI 10.1016/0013-7952(93)90059-L

Robert, H. \& Hack, G.H. (2020). Weathering, erosion, and susceptibility to weathering. Kanji, M.; He, M. \& Sousa, L.R. (eds.), Soft Rock Mechanics and Engineering. Springer, Switzerland, pp. 291-335.

Romano, A.W.; Rezende, L.F.S. \& Macedo, B.O.P. (2017). Ouro Preto Map, SF.23-X-A-III, scale 1:100.000: Triângulo Mineiro Project. CODEMIG, Belo Horizonte (in Portuguese).

Silva, W.G.; França, A.V.M. \& Sampaio, J.L.D. (2005) Mariana Map, SF.23-X-B-I-3 e SF.23-X-B-IV-1, scale 1:50.000: Geology project of the Quadrilátero Ferrífero - Integration and Cartographic Correction in GIS. CODEMIG, Belo Horizonte (in Portuguese).

Silva, C.H.C. \& Lana, M.S. (2012). Influence of slake durability on geotechnical behavior of phyllites of Pau Branco Mine. Rev. Esc. Minas., 65(3):413-418. DOI 10.1590/S0370-44672012000300019

Sarkar, K.; Vishal, V. \& Singh, T.N. (2012). An empirical correlation of index geo-mechanical parameters with the compressional wave velocity. Geotech. Geol. Eng., 30(2):469-479. DOI 10.1007/s10706-011-9481-2

Sharma, P.K.; Khandelwal, M. \& Singh, T.N. (2011). A correlation between Schmidt hammer rebound numbers with impact strength index, slake durability index and 
P-wave velocity. Int. J. Earth Sci., 100(1):189-195. DOI 10.1007/s00531-009-0506-5

Sharma, P.K. \& Singh, T.N. (2008). A correlation between P-wave velocity, impact strength index, slake durability index and uniaxial compressive strength. Bull. Eng. Geol. Environ., 67:17-22. DOI 10.1007/s10064-007-0109-y

Sousa, L.M.O.; Río, L.M.S.D.; Calleja, L.; Argandoña, V.G.R. \& Rey, A.R. (2005). Influence of microfractures and porosity on the physico-mechanical properties and weathering of ornamental granites. Eng. Geol., 77(1):153-168. DOI 10.1016/j.enggeo.2004.10.001

Turgrul, A. \& Zarif, I.H. (1999). Correlation of mineralogical and textural characteristics with engineering proper- ties of selected granitic rocks from Turkey. Eng. Geol., 51(4):303-317. DOI 10.1016/S0013-7952(98)00071-4

Yasar, E. \& Erdogan, Y. (2004). Correlating sound velocity with the density, compressive strength and Young's modulus of carbonate rocks. Int. J. Rock Mech. Min. Sci., 41(5):871-875. DOI 10.1016/j.ijrmms.2004.01.012

Yilmaz, I. \& Karacan, E. (2005). Slaking durability and its effect on the doline formation in the gypsum. Environ. Geol., 47:1010-1016. DOI 10.1007/s00254-005-1234-1

Wen, L.; Luo, Z.; Yang, S.; Qin, Y. \& Wang, W. (2018). Correlation of geo-mechanics parameters with uniaxial compressive strength and P-wave velocity on dolomitic limestone using a statistical method. Geotech. Geol. Eng., $\quad 77(1-2): 153-168 . \quad$ DOI 10.1016/j.enggeo.2004.10.001 